\title{
Development of soil organic carbon pools after vineyard abandonment
}

\author{
Tibor József Novák ${ }^{1 *}$, József Incze ${ }^{1}$, Almuth McLeod ${ }^{2}$, Luise Giani \\ ${ }^{1}$ University of Debrecen, Faculty of Sciences and Technology, Institute of Earth Sciences, Department of Landscape Protection and Environmental \\ Geography, Debrecen, Hungary, Egyetem tér 1. H-4010, Debrecen, Hungary, tel. +36-52-512-900/23221 \\ ${ }^{2}$ Geological Survey Nordrhein-Westfalen, Landesbetrieb, De-Greiff-Straße 195, D-47803, Krefeld, Germany \\ ${ }^{3}$ Carl von Ossietzky University Oldenburg, Institute of Biology and Environmental Sciences, Department of Soil Science, D-26111, Oldenburg, \\ Germany \\ * Associate professor, T.J. Novák, novak.tibor@science.unideb.hu, ORCID iD: https://orcid.org/0000-0002-5514-9035
}

Received: 22.04.2020

Accepted: 22.09.2020

Associated editor: B. Glina

\author{
Keywords \\ Postagricultural soils \\ Chronosequence \\ Organic carbon fractions \\ Free particulate organic matter \\ Occluded particulate organic matter
}

\begin{abstract}
Abandoned vineyard soils show quick recharge of soil organic carbon (SOC) stocks after cancellation of cultivation. In the study abandoned vineyards with six different age classes concerning the duration of postagricultural development, organized along two lines in different exposures on slope (one S and one SW exposed chronosequence) were selected. Involving an additional recently cultivated vineyard location, totally 13 sites were sampled for topsoil characteristics. In each bulk soil sample density fractions, hot water extraction, and microbial samples were separated. Accordingly the $\mathrm{C}$ and $\mathrm{N}$ content and $\mathrm{C} / \mathrm{N}$ ratio of free particulate organic matter (FPOM), occluded particulate organic matter (OPOM), clay-, silt- and sand sized microaggregates, hot water soluble organic matter, and microbial biomass were measured and discussed in the study. We found that labile, active carbon pool (FPOM) have relatively low share of the TOC (in average $11.6 \%$ in S and 4.6\% in SW sequence) and showed no increase with the time since the cancellation of cultivation. Also this pool has generally higher $\mathrm{C} / \mathrm{N}$ ratio (20.6 \pm 3.7$)$, as more stable pools (OPOM: 19.2 \pm 9.6 ; clay fraction: $9.2 \pm 1.2$,). Highest part of TOC is stored in clay-sized microaggregates (in average $37.2 \%$ in S and $41.5 \% \mathrm{SW}$ sequence) and its amount correlates significantly with the time since the cancellation of cultivation. By comparison, in recently cultivated soil lower share of $\mathrm{C}$ in clay sized microaggregates and (24.0\% of TOC) and higher share of labile, FPOM (26.6\% of TOC) was found. C-pools in microbial and hot water extractable $\mathrm{C}$ forms showed significant changes with the time. Based on exposure and cultivation also proved different, anyway, their contribution to TOC are low.
\end{abstract}

\section{Introduction}

Soil organic matter (SOM) could be divided on different fractions according to that, how far it is physically protected against further oxidation and mineralization processes, and how sensitive it responds to changes of land use. Density fractionation of SOM allows differentiation of light, and heavy fractions. In light fractions free particulate organic matter (FPOM), and occluded particulate organic matter (OPOM) could be distinguished according to that, if the SOM is occluded and therefore slightly protected within aggregates, or not. In case of heavy fractions SOM is so inseparably connected to the mineral particles, and therefore it is usually regarded to be a passive pool within SOM. Heavy fraction can be further separated according the particle size distribution, belonging into sand $(2-0.063 \mathrm{~mm})$, silt $(0.063-0.002 \mathrm{~mm})$ and clay $(<0.002 \mathrm{~mm})$ size. Occlusion of SOM into stabile soil aggregates and following stronger connection to mineral particles is regarded as the most important stabilization process of the SOM (Dilly and Blume, 1998).

In consequence of vineyard abandonment and subsequent self-restoration significant C-sequestration in soils considering the total organic carbon (TOC) content (Novák et al., 2014; Spohn et al., 2015) can be observed. Nevertheless, it is unknown which kind of $C$ pools were affected. Many studies show that the conversion of arable land to abandoned soils, or conversion of conventional tillage to no tillage management caused predominantly an increase of the FPOM (Coneiçăo et al., 2013), which belongs to the active $C$ pool, and considered as most sensitive indicator for land use changes.

For the dynamic of different SOM pools during self-restoration of vineyard soils no data are available so far. Hence, the aim of this study was to fill this knowledge gap, and investigate, which fractions contributes most effectively to carbon sequestration during the spontaneous restoration of soils after abandonment of cultivation. 


\section{Materials and methods}

\subsection{Study area}

The study was carried out on the southest part of the TokajHegyalja Wine Region (Hungary), on Tokaj Nagy-Hill (Fig. 1). It is a traditional wine production area with almost thousand years old tradition. The physico-geographical conditions and soil forming factors of the area show big diversity within the area. The hill rises from the alluvial plain of the Bodrog, Tisza and Takta rivers starting at $100 \mathrm{~m}$ and reaches the elevation of $514 \mathrm{~m}$ a.s.l. The main mass of the hill is built up from late Miocene volcanic materials (Pécskay et al., 1995; Rózsa et al., 2006), which are mostly covered by aeolian loess sediments from lower to upper Weichselian ice age and their derivates, as colluvial materials (gravel, blocks, eroded and redeposited loess and soil). On the steepest sections of slopes volcanic rocks outcrop since the rapid erosion removed completely the overlaying loess cover. Remnants of interlayered fossil soil layers and preglacial weathering products of volcanic materials increase the spatial heterogeneity of parent materials of soils. The mean annual temperature varies between $8.5^{\circ} \mathrm{C}$ on the top and almost $10^{\circ} \mathrm{C}$ at the base due to the microclimatic variability influenced by the topography. The average annual number of sunny hours is about 2000-2050. The mean annual precipitation is between 580 and $617 \mathrm{~mm}$ (Justyák, 1981). The duration of snow cover is short, does not reach 40 days and the mean thickness is less than $20 \mathrm{~cm}$. The soil temperature regime could be given in mesic, the soil moisture regime in ustic (Füleky et al., 2007) and presumably xeric in some of the years.

Vegetation, soils, and geomorphology on major part of the hill has been affected by cultivation during the last centuries
(Balassa, 1975, 1991; Rózsa, 2007). The changes of the socio-economic environment during the last centuries were reflected also in land use changes (Boros, 2008) resulting the fluctuation of the extent of cultivated vineyards (Nyizsalovszki and Fórián, 2007). Remarkable part of them were abandoned or restored according the changes of actual demand for wines (Boros, 2008). After abandonment of vineyards spontaneous reforestation and shrub development could start (Sendtko, 1999), which might be interrupted by later restoration of plantations during conjuncture periods.

Soils of the Hill therefore shows also frequently evidence of former or recent disturbances (Novák et al., 2014). Still the high diversity of parent materials, topography, and vegetation and land use history resulted high diversity in soils as well. Earlier studies (Kerényi, 1994; Stefanovits et al., 1999) reported about eroded Luvisols, Chernozems, Phaeozems from the Hill, later on weathering products of volcanic rocks Phaeozems, Luvisols, Cambisols, Leptosols and Umbrisols were described (Füleky et al., 2004, 2007; Madarász et al., 2013). Skeletal soils (Dövényi, 2010) and slope deposits (Kerényi, 1994) were also frequently found, which could be assigned to Leptosols and Regosols according to the WRB.

\subsection{Sampling design and settings}

For study site selection land use change data compiled from historical maps and remotely sensed data were used starting with the I. Military Survey (date: 1783), II Military Survey (1858), III Military Survey (1884), topographic maps from the period of World War II (1940), New Survey Topography Map (1960), Topography Map (1989) and orthophoto from 2010. The extent and location of vineyards were identified, vector-
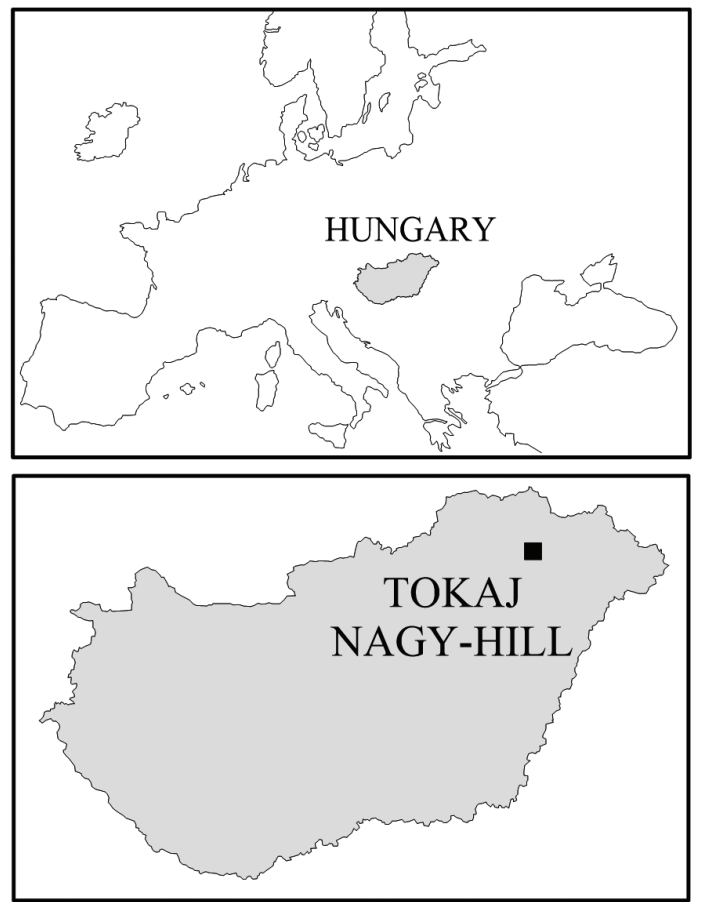

Fig. 1. Location of study area

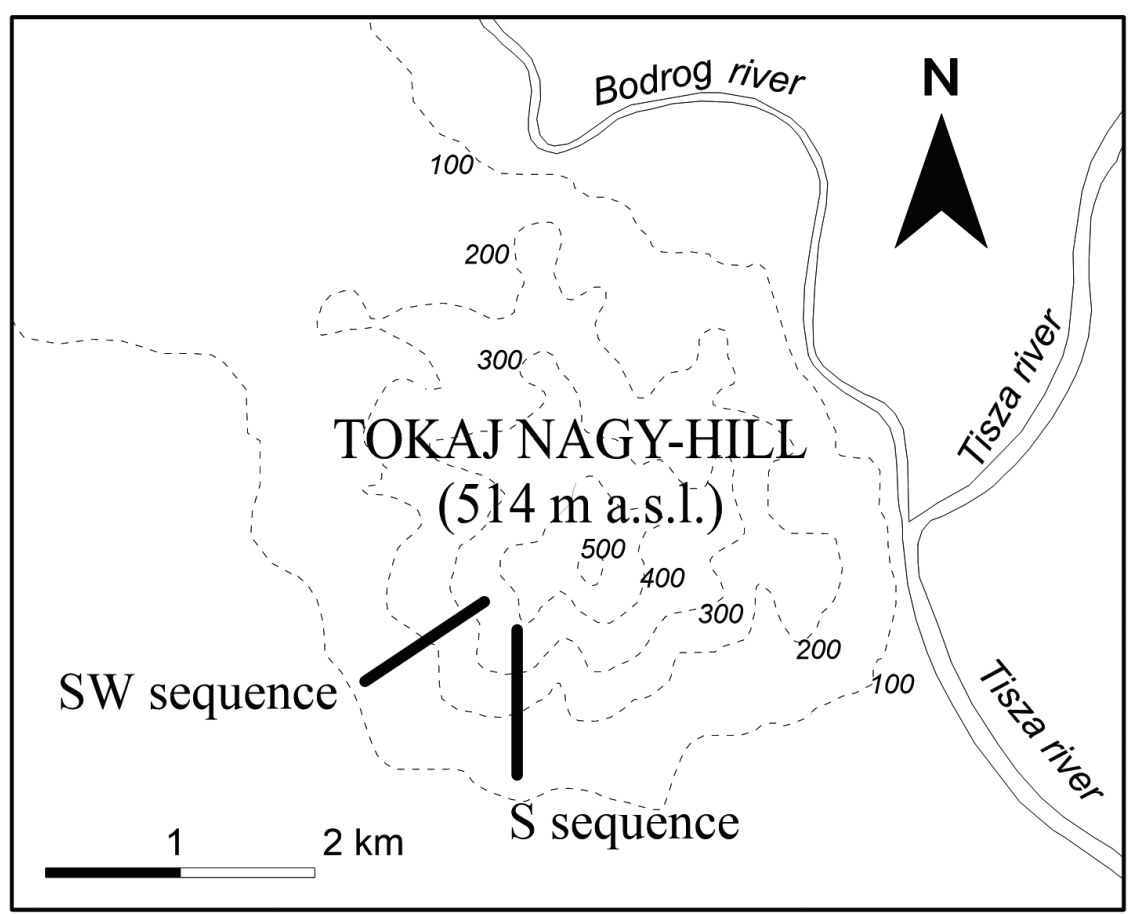


ized and transformed into unified projection system (Unified National Projection, EOV). Elevation deformation of air photographs was offset. For the processing of maps and remotely sensed land use data Quantum GIS 1.7 and Erdas Imagine 8.5 software were applied.

Changes between the mapped periods described the vineyard abandonments between two consecutive maps. The abandoned vineyards were assigned into the following age classes based on the number of years since the abandonment: 193; $142 ; 101 ; 63 ; 39 ; 14$ which are the midpoints of the time intervals between the releases of two consecutive maps. These age classes were delineated with polygons on the maps of the Hill. We supposed, that similarly to other regions slope grade and exposition affect development of soils and vegetation (Koulouri and Giourga, 2007; Leeschen et al., 2008) the study design was extended accordingly. Based on the topographic map the slope gradient and exposition were assigned to the abandonment data. Slope grade categories were applied as in Hungarian agricultural practices $(0-5 \%, 5-12 \%, 12-17 \%, 17-25 \%$ and 25-35\%), exposition was ranked according the four cardinal and four intercardinal directions.

Based on cross sectioning of the slope-grade data, slopeexposition, and abandonment-age map two chronosequences were constituted (Table 1). One sequence was set on $25-35 \%$ slopes exposed to south (S-sequence, sites S1-S6), and one other one on 17-25\% slopes exposed to southwest (SW-sequence, sites SW7-SW12), both including sites of same ages of abandonment (193; 142; 101; 63; 39; 14 years). Depending on the succession grade and time left since abandonment the sampling sites are overgrown by grasslands, shrubs, or secondary forest vegetation. In closest vicinity of S-sequence sites a cultivated vineyard (25\% slope and southwest exposition) was sampled as reference (S/SW0) site.

\subsection{Field soil sampling}

On each sampling site mixed surface samples were collected from the top 0-10 cm layer of soils, in three replicates. The same time soil profiles were prepared, sampled, and described to classify the soils according the WRB. A detailed description of soil profiles, and vegetation and the evaluation of carbon stocks was published by Novák et al. (2014). From the evaluation of carbon fractions subsequently the data of sampling site SW9 were excluded due to visible evidence of later disturbances affecting the shallow topsoil.

\subsection{Standard soil analytics}

Bulk soil samples were grounded to fine powder with a ball mill for 5 minutes and dried at $105^{\circ} \mathrm{C}$ for 24 hours. For the exact determination of soil texture class grain size distribution was analyzed by combined wet sieving (2-0.2 $\mathrm{mm}$ fractions) and pipette method ( $<0.2 \mathrm{~mm}$ fractions) (Pansu and Gatheyrou, 2006). Total organic carbon of bulk samples were determined by both wet oxidation method (Ponomareva and Plotnikova, 1980) and using CHNS analyzer (Flash EA CHNS 112 series, Thermo Electron Cooperation). $\mathrm{pH}_{\mathrm{H} 2 \mathrm{O}}$ and $\mathrm{pH}_{\mathrm{KCl}}$ were measured in 1:2.5 suspensions with standard glass electrode. Inorganic carbon in both, in bulk soil and fractionated samples were measured by volumetric calcimeter (Scheibler) method (Chaney et al., 1982).

Table 1

Sampling site characteristics

\begin{tabular}{|c|c|c|c|c|c|c|}
\hline $\begin{array}{l}\text { Sampling } \\
\text { site }\end{array}$ & $\begin{array}{l}\text { Elevation a.s.l. } \\
\text { (meter) }\end{array}$ & Exposition & Slope & $\begin{array}{l}\text { Time since } \\
\text { abandonment } \\
\text { (years) }\end{array}$ & Vegetation type & WRB RSG \\
\hline S1 & 362 & $S$ & $25-35 \%$ & 193 & Forest & Calcisol \\
\hline S2 & 305 & & & 142 & Grassland/shrub & Leptosol \\
\hline S3 & 203 & & & 101 & Shrub & Calcisol \\
\hline S4 & 233 & & & 63 & Grassland/shrub & Calcisol \\
\hline S5 & 155 & & & 39 & Grassland/shrub & Calcisol \\
\hline S6 & 114 & & & 14 & Fallow & Regosol \\
\hline SW7 & 426 & SW & $17-25 \%$ & 193 & Forest & Chernozem \\
\hline SW8 & 377 & & & 142 & Afforestation & Cambisol \\
\hline SW9 & 335 & & & 101 & Forest & Cambisol \\
\hline SW10 & 275 & & & 63 & Grassland & Phaeozem \\
\hline SW11 & 236 & & & 39 & Shrub & Cambisol \\
\hline SW12 & 257 & & & 14 & Fallow/shrub & Regosol \\
\hline S/SW0 & 145 & SSW & $25 \%$ & 0 & Cultivated vineyard & Regosol \\
\hline
\end{tabular}




\subsection{Soil organic matter fractionation}

\subsubsection{Density fractions}

The SOM fractionation was conducted to obtain light $\left(<1.8 \mathrm{~g} \mathrm{~cm}^{-3}\right)$ fractions (FPOM and OPOM) and OM of the heavy $\left(>1.8 \mathrm{~g} \mathrm{~cm}^{-3}\right)$ fractions (associated with grain size fractions as sand, silt and clay) according to Kalinina et al. (2009, 2010, 2011, 2015) (Fig. 2).

The fractionation was carried out on dried $\left(105^{\circ} \mathrm{C}\right)$ and sieved ( $2 \mathrm{~mm}$ ) soil samples in portions of $7 \mathrm{~g}$ per measurement. Fractionation and measurements were done in triplicates. To separate light and heavy fractions a sodium polytungstate (SPT) solution with a special density of $1.8 \mathrm{~g} \mathrm{~cm}^{-3}$ were used to soak soil aggregates and particles for 12 hours. The FPOM fractions were separated as the overfloating soil particles (lighter than $1.8 \mathrm{~g} \mathrm{~cm}^{-3}$ ) due filtration by cellulose-nitrate membrane filters $(1.2 \mu \mathrm{m})$. Before determining the weight of the light fractions remained on the filter, SPT solution had to be removed from the filtrate (Ahmed and Oades, 1984) therefore after each filtration, the soil was washed with deionized water and the washwater's electrical conductivity was measured until having values lower than $100 \mathrm{~S} \mathrm{~cm}^{-1}$. To determine the separate's weight, the filtered and washed soil fraction was dried at $105^{\circ} \mathrm{C}$.
To gain the OPOM fractions in the next step the heavy fractions (heavier than 1:8 $\mathrm{g} \mathrm{cm}^{-3}$ ) were dispersed with help of ultrasonic sound treatments in order to crack aggregates and free the OPOM. Optimization of the energy intensity was necessary, to avoid destroying organo-mineral complex, and mutate grain size distribution applying to high energy, or preserving uncracked aggregates and underestimate of the OPOM by applying to low energy (Leifeld and Kögel-Knabner, 2005; Schmidt et al., 1999; Steffens et al., 2009). For determination of the optimal treatment time a sonotrode was carried out by measuring the heating of $100 \mathrm{ml} \mathrm{H}_{2} \mathrm{O}$ during a time of 120 seconds. The resulting time for treating the samples was calculated and set to $10 \mathrm{~min}-$ utes, whereby approximately $450 \mathrm{Jml}^{-1}$ energy output had been reached. The aggregates after this treatment were cracked and the OPOM lighter than $1.8 \mathrm{~g} \mathrm{~cm}^{-3}$ freed. Ultrasound dispersion was followed by centrifugation (15 minutes at a speed of 10000 spins per minute) and again filtering, washing, drying.

The left-over heavy soil fractions (heavier than $1: 8 \mathrm{~g} \mathrm{~cm}^{-3}$ ) of all three parallels were mixed together for grain size analysis without $\mathrm{H}_{2} \mathrm{O}_{2}$ pre-treatment to avoid destruction of organo-mineral complexes. Therefore the separated fractions are not in fact mineral grain particles but are denominated as i.e. sand sized $(2-0.63 \mathrm{~mm})$, silt sized $(0.63-0.002 \mathrm{~mm})$, and clay sized

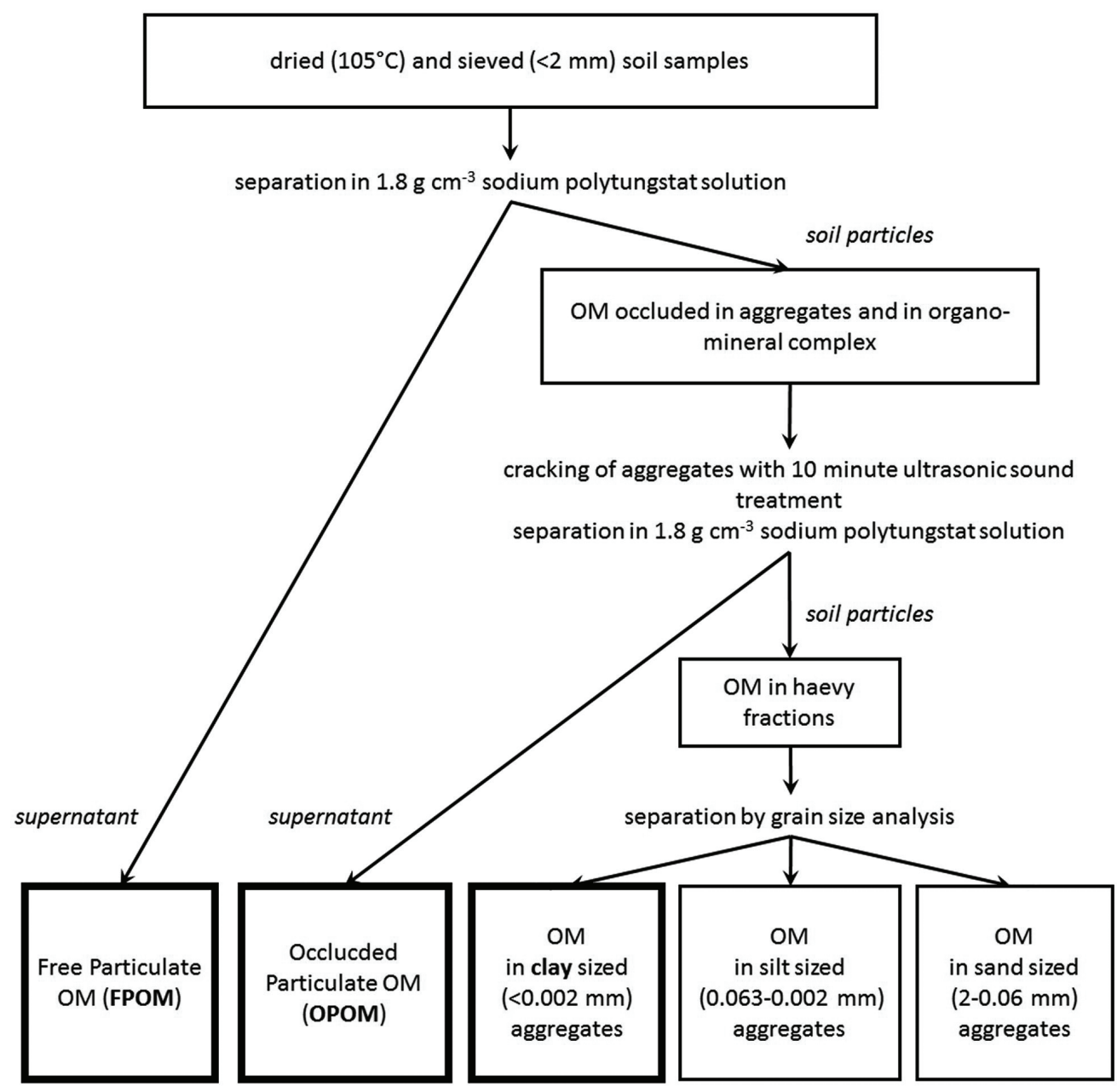

Fig. 2. Processing of separation of OM fractions 
(<0.002 mm) microaggregates according definitions (Blume et al., 2011).

From each separated fraction $2 \mathrm{mg}$ was weighed for $\mathrm{C} / \mathrm{N}$ analysis in triplicates.

The amounts of OC in particular fractions $\left(\mathrm{g} \cdot \mathrm{kg}^{-1} \mathrm{soil}\right)$ were calculated as follows:

$\mathrm{OC}_{\mathrm{i}}=\frac{\mathrm{F}_{\mathrm{i}}}{\sum_{\mathrm{i}=1}^{\mathrm{n}} \mathrm{F}_{\mathrm{i}}} \cdot \mathrm{C}_{\mathrm{i}} \cdot 100$

where $\mathrm{OC}_{\mathrm{i}}$ is the amount of $\mathrm{OC}$ in $\mathrm{i}$ fraction in $\mathrm{g}$ in $1 \mathrm{~kg}$ of soil $\left(\mathrm{g} \cdot \mathrm{kg}^{-1}\right), \mathrm{F}_{\mathrm{i}}$ is the mass of the $\mathrm{i}$ fraction in $\mathrm{kg}, \mathrm{C}_{\mathrm{i}}$ is the concentration of organic $\mathrm{C}$ in $\mathrm{i}$ fraction in $\mathrm{g} \cdot \mathrm{kg}^{-1}$. In a similar way the amounts of $\mathrm{N}$ for each fraction were calculated.

\subsubsection{Hot water extractable $\mathrm{C}\left(\mathrm{C}_{\mathrm{hwe}}\right)$}

Hot water extractable $\mathrm{C}\left(\mathrm{C}_{\mathrm{hwe}}\right)$ was gained by reflushing $5 \mathrm{~g}$ of soil with $25 \mathrm{ml}$ of $\mathrm{H}_{2} \mathrm{O}_{\text {dest }}$ for 60 min with an attached reflux condenser, which was prewetted previously with $25 \mathrm{ml}$ moderately boiling distilled water, following the VDLUFA-Methodenbuch, (2004)). Subsequently, the samples were cooled down in a water bath to room temperature, 2 droplets of $\mathrm{MgSO}_{4}$ solution $\left(490 \mathrm{~g} \cdot \mathrm{l}^{-1}\right)$ were added and was centrifuged (3500 U/min with Labofuge 400/Heraeus company/swing-bucket rotor) for $10 \mathrm{~min}$ utes at $2600 \mathrm{~g}$. The supernatant was filtered through a $0.45 \mu \mathrm{m}$ nitrocellulose filter (Millipore), acidified to $\mathrm{pH} 2$ with $6 \mathrm{M} \mathrm{HCl}$ (10 $\mathrm{ml}$ filtrate $+40 \mu \mathrm{l} 6 \mathrm{M} \mathrm{HCl}$ ) to prevent possible $\mathrm{CO}_{2}$ absorption from the air, and stored at $4^{\circ} \mathrm{C}$. The $\mathrm{C}_{\text {hwe }}$ concentration was measured using a TOC analyzer (TOC-V CSH, Shimadzu) and calculated for $\mathrm{g} \mathrm{kg}^{-1}$.

\subsubsection{Microbial C $\left(\mathrm{C}_{\mathrm{m}}\right)$}

Microbial C was determined according to Vance et al. (1987). Five g sieved, field moist soil was fumigated with chloroform for $24 \mathrm{~h}$ and was subsequently extracted in $0.5 \mathrm{MK}_{2} \mathrm{SO}_{4}$ for 1 hour on a shaker. Another $5 \mathrm{~g}$ were directly extracted in $0.5 \mathrm{M} \mathrm{K}_{2} \mathrm{SO}_{4}$ for $1 \mathrm{~h}$ on a shaker. The organic $\mathrm{C}$ in both extracts was determined with a CN Analyzer (Multi 2100 Analytik Jena) after acidification to $\mathrm{pH} 3$ in order to remove inorganic $\mathrm{C}$. The difference between the organic $\mathrm{C}$ in the extract of the fumigated and the non-fumigated soil was multiplied by the conversion factor 2.64 for C (Vance et al., 1987), and the result of this multiplication is considered as the microbial $\mathrm{C}$.

\subsection{Chemical analysis}

Total carbon (TC) and total nitrogen (TN) content in bulk soil samples and in particular fractions were measured with a CHNS analyzer (Flash EA CHNS 112 series, Thermo Electron Cooperation) after the fractionations were separated by the above-mentioned way. Three repetitions were conducted per measurement. The amount of TC and TN are given in $\mathrm{m} / \mathrm{m} \%$ and calculated to $\mathrm{g} \mathrm{kg}^{-1}$. The standard values used for this measurement are $10.36 \%$ for $\mathrm{N}$ and $69.38 \%$ for C.

Inorganic carbon content in the bulk soil samples and in density fractions were measured by volumetric method (Schei- bler calcimeter), and total carbon data were corrected with the measured values to calculate the total organic carbon (TOC). Since inorganic carbon was found almost exclusively in sand and silt fractions in higher amount, which could influence strongly the results of carbon measurements, in the fractionated carbon content only the clay and the light organic carbon fractions were taken into consideration.

\subsection{Data analysis and evaluation}

Before statistical analysis of relationships between variables, all datasets were tested for normality with KolmogorovSmirnov test, and the equal variance of homogeneity. Since we found the data not to follow normal distribution, non-parametric statistical tests (Spearman's rank correlation) were applied. Statistical analyses were performed using SPSS 17.0. Since carbon content of density fractions (FPOM, OPOM, and heavy fractions) are overlapping with $\mathrm{C}_{\mathrm{m}}$ and $\mathrm{C}_{\mathrm{hwe}}$, the evaluation was carried out separately for density fractions and $\mathrm{C}_{\mathrm{hwe}}$ and $\mathrm{C}_{\mathrm{m}}$.

\section{Results}

\subsection{Dynamic of TOC and TN}

The TOC concentrations in S-sequence were varying between $11.03 \mathrm{~g} \mathrm{~kg}^{-1}$ (S6) and $45.59 \mathrm{~g} \mathrm{~kg}^{-1}$ (S1) values were increasing with the age of abandonment (Table 2). In comparison the cultivated reference site (S/SW0) had $14.85 \mathrm{~g} \mathrm{~kg}^{-1}$. In the SW-sequence lowest TOC-concentration was also measured in most recent abandonment $5.30 \mathrm{~g} \mathrm{~kg}^{-1}$ (SW12), and the oldest abandoned site had $26.96 \mathrm{~g} \mathrm{~kg}^{-1}$ (SW7). The increase of TOC concentration showed significant correlation with the duration of abandonment in both sequences. Spearman's rho was in case of S-sequence $0.786(p<0.05)$ in SW-sequence $0.886(p<0.01)$.

TN-concentration in S-sequence was also increasing with years since abandonment from $0.835 \mathrm{~g} \mathrm{~kg}^{-1}$ in the youngest (S6), and $5.076 \mathrm{~g} \mathrm{~kg}^{-1}$ in the oldest abandonment (S1). The TN concentration correlates significantly with the years since abandonment (Spearman's rho $=0.965 ; \mathrm{p}<0.01$ ). We measured the lowest TN concentration in the cultivated reference site (S/SW0) $0.276 \mathrm{~g} \mathrm{~kg}^{-1}$. In case of the SW-sequence, similarly to the TOC, TN concentrations were lower consequently. In most recent abandoned site (SW12) TN concentration was $0.523 \mathrm{~g} \mathrm{~kg}^{-1}$, in the oldest abandonment (SW7) $2.383 \mathrm{~g} \mathrm{~kg}^{-1}$. TN increase with the time since abandonment proved to be significant in case of SW-sequence as well (Spearman's rho $=0.872 ; \mathrm{p}<0.05$ ).

\subsection{Dynamics of fractionated SOC pools}

In average $82.1 \%$ of OC was found in clay and light (OPOM and FPOM) fractions, and only $17.9 \%$ in silt and sand sized particles, additionally the inorganic carbonates were found mostly in silt and sand fractions which variated on wide range depending from carbonate contents of parent material, therefore only OC in clay and light (OPOM, FPOM) fractions were evaluated separately. 
Table 2

Amount and share of organic carbon in fractions of soil organic matter in abandoned vineyard soils\#

\begin{tabular}{|c|c|c|c|c|c|c|c|c|c|c|c|}
\hline \multirow{2}{*}{$\begin{array}{l}\text { Sampling } \\
\text { site }\end{array}$} & \multicolumn{6}{|c|}{ Density fractions } & \multicolumn{2}{|c|}{$\mathrm{OC}_{\text {hwe }}$} & \multicolumn{2}{|l|}{$\mathrm{C}_{\mathrm{m}}$} & \multirow{2}{*}{$\begin{array}{l}\text { TOC } \\
\mathrm{g} / \mathrm{kg} \\
\text { (bulk } \\
\text { soil) }\end{array}$} \\
\hline & \multicolumn{2}{|c|}{ FPOM$^{*}$} & \multicolumn{2}{|c|}{$\mathrm{OPOM}^{* *}$} & \multicolumn{2}{|c|}{ clay sized } & $\mathrm{g} / \mathrm{kg}$ & $\%$ of TOC & $\mathrm{g} / \mathrm{kg}$ & $\%$ of TOC & \\
\hline S1 & 9.35 & $20.5 \%$ & 14.04 & $30.8 \%$ & 17.18 & $37.8 \%$ & 1.83 & $4.0 \%$ & 0.321 & $0.7 \%$ & 45.51 \\
\hline S3 & 3.42 & $7.5 \%$ & 13.50 & $29.6 \%$ & 16.47 & $36.1 \%$ & 1.81 & $4.0 \%$ & 0.294 & $0.6 \%$ & 45.59 \\
\hline S4 & 4.10 & $11.3 \%$ & 8.01 & $22.1 \%$ & 13.99 & $38.7 \%$ & 1.51 & $4.2 \%$ & 0.360 & $0.9 \%$ & 36.18 \\
\hline S5 & 4.46 & $19.3 \%$ & 1.06 & $4.6 \%$ & 8.17 & $35.3 \%$ & 1.42 & $6.1 \%$ & 0.284 & $1.2 \%$ & 23.15 \\
\hline S6 & 1.37 & $12.4 \%$ & 4.02 & $36.5 \%$ & 2.97 & $26.9 \%$ & 0.38 & $3.4 \%$ & 0.060 & $0.5 \%$ & 11.03 \\
\hline SW10 & 0.41 & $2.3 \%$ & 8.32 & $46.8 \%$ & 6.42 & $36.1 \%$ & 0.87 & $4.9 \%$ & 0.101 & $0.6 \%$ & 17.79 \\
\hline SW11 & 1.18 & $6.6 \%$ & 7.19 & $40.2 \%$ & 7.27 & $40.7 \%$ & 1.05 & $5.8 \%$ & 0.134 & $0.7 \%$ & 17.87 \\
\hline SW12 & 0.21 & $4.0 \%$ & 2.09 & $39.5 \%$ & 2.61 & $49.3 \%$ & 0.45 & $8.5 \%$ & 0.177 & $3.3 \%$ & 5.30 \\
\hline S/SW/0 & 3.95 & $26.6 \%$ & 4.76 & $32.0 \%$ & 3.57 & $24.0 \%$ & 0.34 & $2.3 \%$ & 0.105 & $0.7 \%$ & 14.85 \\
\hline
\end{tabular}

*FPOM = free particulate organic matter;

**OPOM = occluded particulate organic matter

OC content of OPOM and the clay fractions proved to be in significant correlation $(p<0.01)$ with the TOC of the samples, therefore similarly to TOC they increased with the time since abandonment. Spearman's rho in case of heavy (clay) fraction was 0.961 ( $p=0.0001)$, and in case of OPOM fraction was 0.807 $(p=0.001)$. The OC content of FPOM fractions do not show significant relation to the TOC content, therefore also not related with the time since abandonment (Fig. 3).

The clay fraction contained the highest proportion of TOC in every case, in exception of the recently cultivated S/SW0, where
OC content of both OPOM and FPOM fractions exceeded the OC content of clay fraction. After the clay-sized particles, the second largest OC pool proved to be in the OPOM fraction, with exception of the 39 years old abandonment of S-sequence (S5) and the cultivated reference (S/SW0) samples, where OC content of FPOM was higher.

Highest proportion of light POM (OPOM and FPOM) within the TOC was found in the cultivated site (S/SW0) 52.5\%. In abandoned soils the contribution of light POM to the TOC was substantially lower, in average $26.3 \%$ in S-sequence, and $11.8 \%$ in
Fig. 3. OC in fractions (clay, OPOM, FPOM) plotted against the TOC content of samples

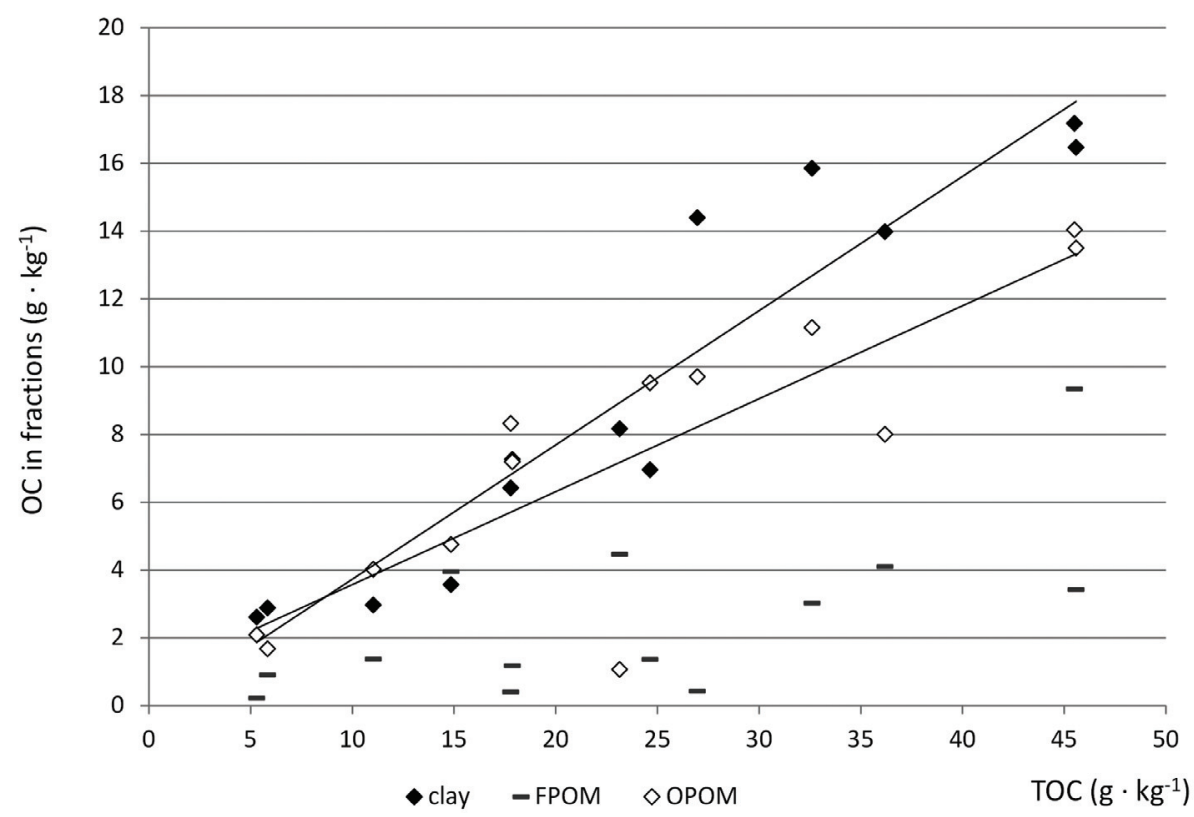


SW-sequence. Consequently, low proportion of TOC was found in clay sized POM in case of the cultivated S/SW0 reference site (47.5\%), and much higher part of it in cases of abandoned soils: $73.3 \%$ in S-sequence, and $88.2 \%$ in SW-sequence in average.

The OC content of OPOM and clay fractions increased significantly with the time since abandonment of the cultivation parallel with the TOC content of the samples in both, S- and SW-sequences (Fig. 4). In S-sequence the OC content of clay fraction showed stronger relation with time and faster growth (Spearman's rho $=0.929 ; \mathrm{p}<0.01$ ) than OC content of the OPOM fraction (Spearman's rho $=0.821 ; \mathrm{p}<0.05$ ). In the SW-sequence the increase OC content was faster in case of OPOM (Spearman's rho $=0.943 ; \mathrm{p}<0.01$ ), than in clay fraction (Spearman's rho $=0.8771 ; p<0.05$ ). In case of FPOM no significant relation with the duration of self-restoration was found in none of the sequences (Fig. 4).
Contribution of $\mathrm{C}_{\mathrm{m}}$ to the TOC of the bulk soil proved to be evenly very low, in average $0.75 \%$ in the $S$, and $1.13 \%$ in the SW sequence. It was in both cases higher than in the reference cultivated S/SW0 site (0.71\%). Lower $\mathrm{C}_{\mathrm{m}}$ contribution and activity in the $S$ sequence are related to the limited access to soil moisture on these exposed slopes. Lowest contribution in case of the cultivated S/SW0 site refers to reduced microbial life under cultivated soil conditions.

\subsection{Dynamics of $\mathrm{N}$ in fractions}

Parallel with the TOC content N content showed an increasing dynamic with the time in both $\mathrm{S}$ and SW sequences. Highest part of TN was stored in almost every samples in clay fraction, followed by the OPOM fraction, and lowest in FPOM (Fig. 5).

\section{S-sequence}

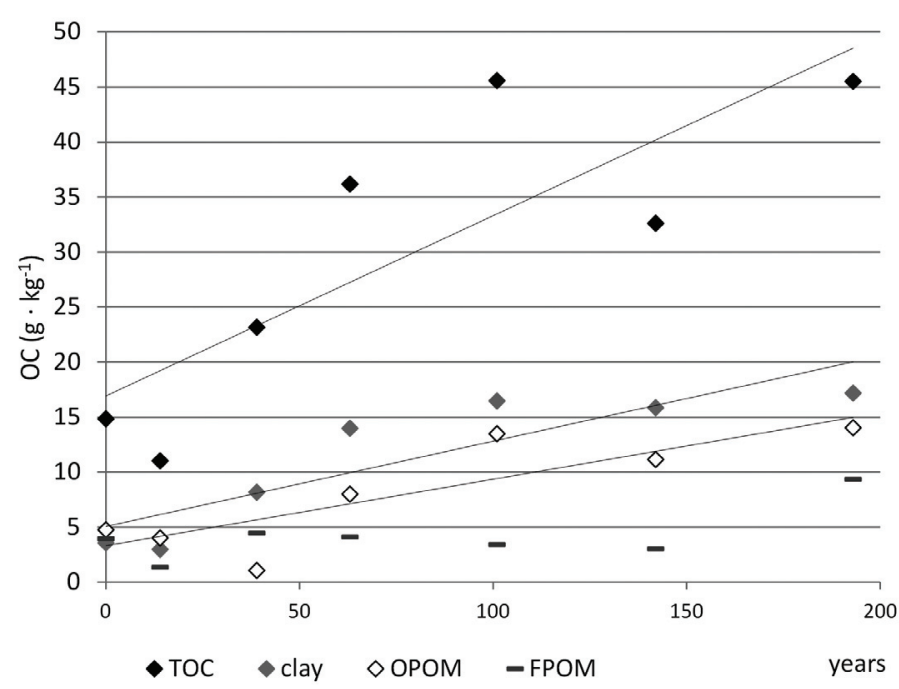

SW-sequence

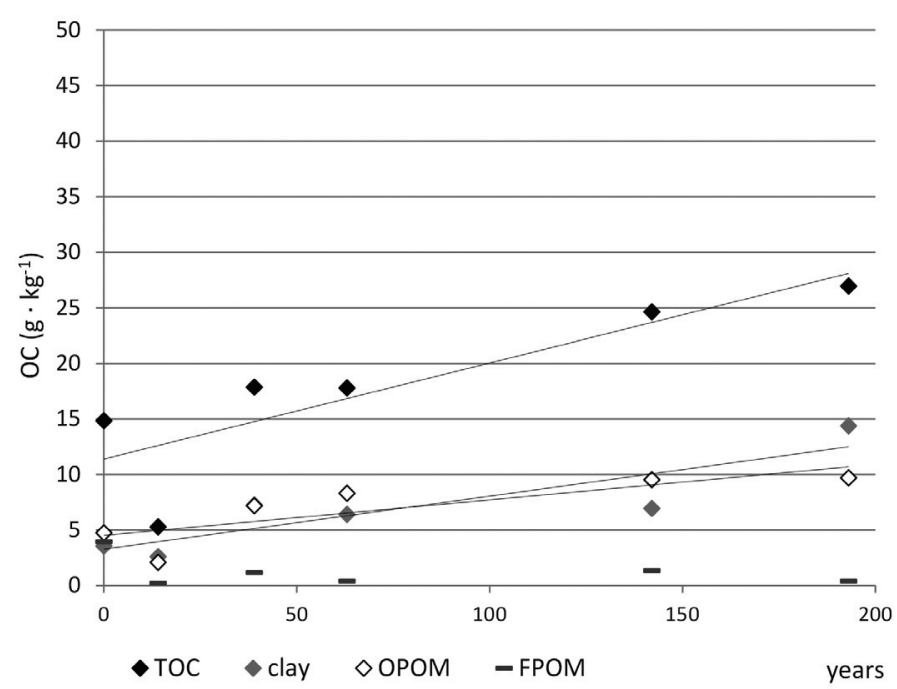

Fig. 4. Changes of OC content in fractions (clay, OPOM, FPOM) after abandonment in S- and SW-sequence
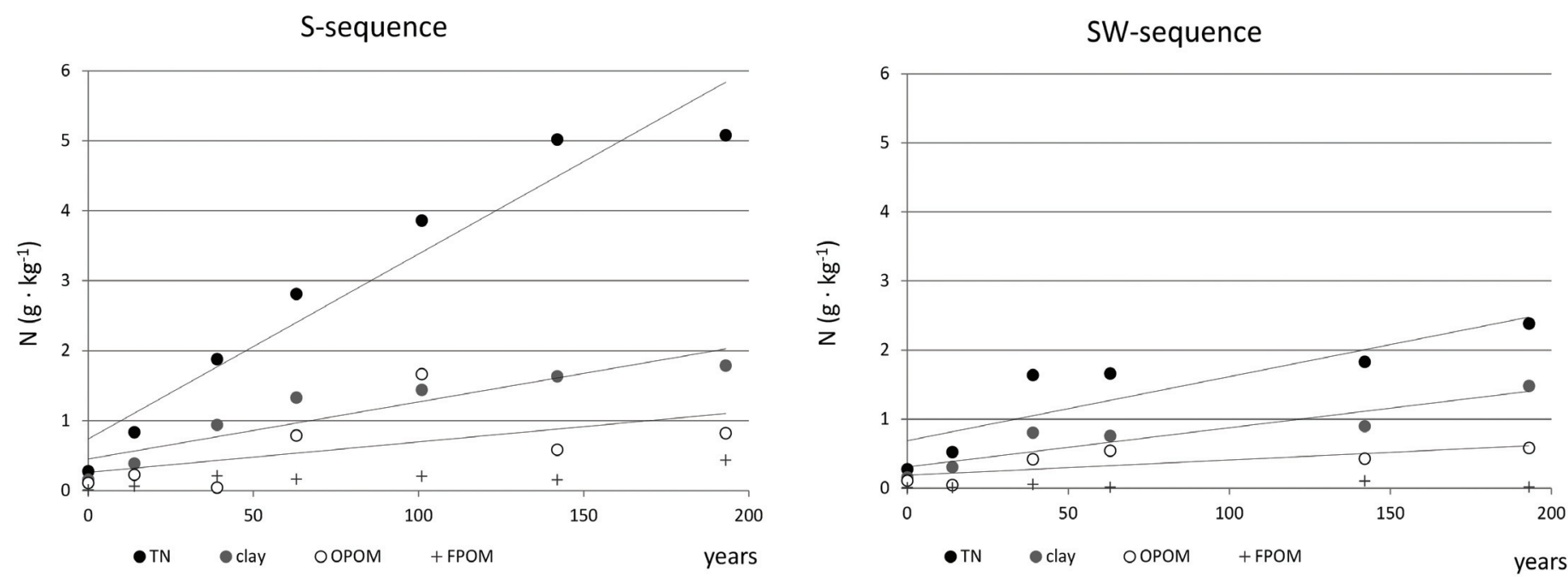

Fig. 5. Changes of total $\mathrm{N}$ content in fractions (clay, OPOM, FPOM) after abandonment in S- and SW-sequence 


\subsection{Dynamics of $\mathrm{C}_{\mathrm{hwe}}$ fraction}

$\mathrm{C}_{\mathrm{hwe}}$ represents the relatively stable but small part of the TOC pool. Respectively, highest values were measured in the samples with higher postagricultural development, and it shows significant increase with the time (Fig. 6). Anyway, it contributes to the TOC only in very low amount, varying between 0.38 and $1.83 \mathrm{~g} \mathrm{~kg}^{-1}$ in abandoned soils and having the lowest value in the cultivated soil $\left(0.34 \mathrm{~g} \mathrm{~kg}^{-1}\right)$.

Fig. 6. $\mathrm{OC}_{\mathrm{hwe}}$ fraction and their relation to the time in the two chronosequences

\section{Table 3}

$\mathrm{C} / \mathrm{N}$ ratio in bulk soil and in investigated fractions of soil organic matter

\section{5. $\mathrm{C} / \mathrm{N}$ ratio in total soil and in fractions}

$\mathrm{C} / \mathrm{N}$ ratio of the not fractioned samples proved to be slightly different in the two sequences: $11.1( \pm 3.2)$ in S- and $10.6( \pm 1.9)$ SW-sequence (Table 3). In fractioned samples of the $S$ sequence the highest $\mathrm{C} / \mathrm{N}$ values were found in FPOM $20.1( \pm 1.01)$. In the OPOM it was lower, $16.2( \pm 3.1)$, and in clay sized fraction was the lowest $9.7( \pm 0.7)$. In the $\mathrm{SW}$ sequence the $\mathrm{C} / \mathrm{N}$ values of $\mathrm{FPOM}$ and OPOM fractions were similar $21.1( \pm 2.5)$ and $22.4( \pm 5.9)$, consecutively. In clay sized fraction it was lowest, 8.7 (0.4).

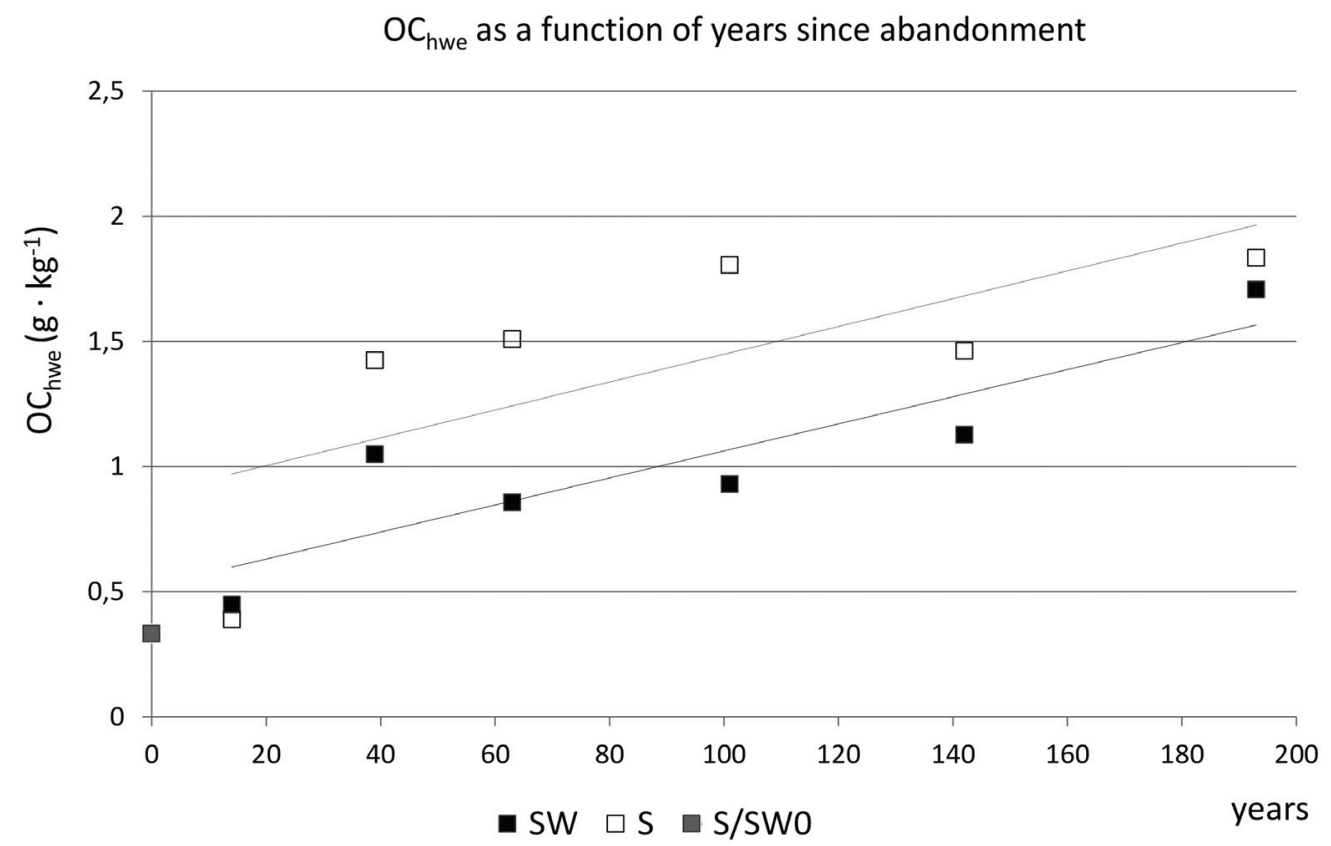

\begin{tabular}{|c|c|c|c|c|c|}
\hline \multirow{4}{*}{$\begin{array}{l}\text { Sampling } \\
\text { site }\end{array}$} & \multicolumn{5}{|l|}{$\mathrm{C} / \mathrm{N}$ ratio } \\
\hline & \multirow[t]{3}{*}{ Bulk soil } & \multicolumn{3}{|c|}{ Density fractions } & \multirow[t]{3}{*}{$\mathrm{OC}_{\text {hwe }}$} \\
\hline & & \multicolumn{2}{|c|}{ Light fractions } & Heavy fraction & \\
\hline & & FPOM & OPOM & clay sized & \\
\hline S1 & 8.97 & 21.5 & 17.1 & 9.61 & 11.9 \\
\hline S2 & 6.50 & 19.5 & 19.1 & 9.71 & 14.0 \\
\hline S3 & 9.38 & 19.8 & 4.81 & 9.72 & 13.9 \\
\hline S4 & 16.2 & 21.0 & 17.2 & 12.4 & 14.3 \\
\hline S5 & 12.3 & 21.0 & 25.3 & 8.69 & 11.8 \\
\hline S6 & 13.2 & 22.1 & 17.7 & 7.65 & 11.4 \\
\hline SW7 & 11.3 & 22.4 & 16.6 & 9.72 & 18.7 \\
\hline SW8 & 13.5 & 13.0 & 22.2 & 7.76 & 11.5 \\
\hline SW9 & 7.39 & 23.0 & 26.7 & 7.71 & 14.7 \\
\hline SW10 & 10.7 & 25.8 & 15.3 & 8.46 & 9.47 \\
\hline SW11 & 10.9 & 20.5 & 17.1 & 9.02 & 12.8 \\
\hline SW12 & 10.1 & 26.8 & 47.0 & 8.51 & 13.1 \\
\hline S/SW0 & 8.06 & 16.0 & 12.1 & 9.86 & \\
\hline
\end{tabular}




\section{Discussion}

In contrast to other studies (John et al., 2005; Poeplau and Don, 2013) with development to forest vegetation we found less $\mathrm{C}$ sequestered in FPOM fractions, and it is not increasing with the time. The reason for this might be, that it must be differentiated among forest types developing during the secondary succession and the quality of the produced biomass. Much FPOM is always related to forests with 'moder' and 'rohhumus' organic layers, producing much more FPOM than forest sites with 'mull' layers, which was the case in our study.

Particulate organic matter (POM) responds often more rapidly to land use conversions or changes in management practice (Leifeld and Kögel-Knabner, 2005; Six et al., 1998), than heavy fractions. Conversion of cultivated land to forest or grasslands results in rapid growing of POM under wet temperate climatic conditions (Poeplau and Don, 2013). Peoplau and Don (2013) also found POM to be a very sensitive indicator of changed SOC sequestration pattern after land use change. Other studies show additionally an increasing change of POM in aggregates (Kalinina et al., 2014, 2015). Passive OC pools (OC in silt and clay fractions (Christensen, 2001) were found to participate in the process of OC sequestration during selfrestoration (Jastrow, 1996; McLauchlan, 2006; Floote and Grogan, 2010) however others shows no substantial participation of this fractions.

Similarly to statements in other studies, smallest contribution to TOC was found in FPOM, and highest in the mineral (clay) fraction (Coneiçăo et al., 2013), anyway differences between the $\mathrm{S}$ and SW sequences and the cultivated reference place were considerable. Only $4.0 \%$ of the TOC took place in FPOM in average of the samples from SW-sequence, $13.4 \%$ in average of S-sequence and $26.6 \%$ in case of the cultivated reference (S/SW) site. This relation proved to be not varying with the time since the abandonment, but the difference between the S and SW sequences was significant. In contrast of other studies, we did not find increasing amount of FPOM, which could be because of the shortest turnover time of this fraction. It seems to be, that in these conditions (dry microclimatic conditions on exposed slopes) SOM of FPOM will be either quickly decomposed or moved into the OPOM and the heavy OM fractions.

The $\mathrm{C} / \mathrm{N}$ ratio was more variable within the different fractions and did not show any clear development with the time of self-restoring. Generally the lowest $\mathrm{C} / \mathrm{N}$ ratio was found in clay fraction $9.2 \pm 1.2$ and in both of the light fractions were more than double higher, being $19.3 \pm 9.7$ in OPOM and $20.6 \pm 3.7$ in FPOM.

\section{Conclusions}

The chronosequential study of the SOC sequestration after vineyard abandonment on S and SW exposed slopes showed that the separate fractions have different contributions to increase of th TOC content. Considering the duration of postcultivation development of the soils a relatively quick $\mathrm{C}$ seques- tration rate could be pointed on, which is also influenced by the slope exposition. The well-known considerable $C$ decrease and exhaustion of $\mathrm{C}$ pools caused by vineyard land use can be the reason for the fast recharge of them after leaving off it. $\mathrm{Al}$ most independently from the duration of postagricultural soil development, the largest part of TOC is stored in form of stable organic compounds bound in clay-sized microaggregates. The contribution of the labile fractions (FPOM, OPOM) to the TOC proved to be relatively low in abandoned vineyards soils, since in the cultivated vineyard soil it is significantly higher - besides lower TOC content. More labile pools (FPOM) represent very limited capacity, even if presumably the $\mathrm{C}$ in this fraction is the first steps in $\mathrm{C}$ sequestration, providing sources to sequester the $\mathrm{C}$ in further, more stable pools, but this process proved to be rapid under the conditions of our study.

\section{Acknowledgements}

The research was financed by the Higher Education Institutional Excellence Programme (NKFIH-1150-6/2019) of the Ministry of Innovation and Technology in Hungary, within the framework of the $4^{\text {th }}$ thematic programme of the University of Debrecen. Research work of Tibor József Novák was supported by the János Bolyai Research Scholarship of the Hungarian Academy of Sciences (BO/00448/17/10) and by the ÚNKP-19-4-DE-129 new national excellence program of the Ministry for Innovation and Technology.

\section{References}

Ahmed, M., Oades, J.M, 1984. Distribution of organic matter and adenosine triphosphate after fractionation of soils by physical procedures. Soil Biology and Biochemistry 16, 465-470. https://doi.org/10.1016/00380717(84)90053-1

Balassa, I., 1975. Phylloxera in Tokaj-Hegyalja . [In:] Szabadfalvi J. (Ed.), Yearbook of Hermann Ottó Museum. Miskolc, 13-15, 305-335. (in Hungarian)

Balassa, I., 1991. Tokaj-Hegyalja szőlője és bora.Vineyards and wines of Tokaj-Hegyalja. Tokaj-Hegyaljai ÁG. Borkombinát. Tokaj, 752. (in Hungarian)

Blume, H-P., Stahr, K., Leinweber, P., 2011. Bodenkundliches Praktikum. Spektrum Akademischer Verlag, Heidelberg.

Boros, L., 2008. Development and types of uncultivated land in TokajHegyalja wine region. Földrajzi Közlemények 132(2), 145-156. (in Hungarian)

Chaney, R.C., Slonim, S.M., Slonim, S.S., 1982. Determination of Calcium Carbonate Content in Soils. [In:] Chaney, R.C., Demars, K.R. (Eds.), Geotechnical properties, behavior, and performance of calcareous soils. American Society for Testing and Materials, Philadelphia-Baltimore, 3-16.

Christensen, B.T., 2002. Physical fractionation of soil and structural and functional complexity in organic matter turnover. Eurasian Journal of Soil Science 52, 345-353. https://doi.org/10.1046/j.13652389.2001.00417.x

Coneiçăo, P.C., Dieckow, J. Bayer, C., 2013. Combined role of no-tillage and cropping system in soil carbon stocks and stabilization. Soil \& Tillage Research 129, 40-47. https://doi.org/10.1016/j.still.2013.01.006

Dilly, O., Blume, H.P., 1998. Indicators to assess sustainable land use with reference to soil microbiology. Advances in GeoEcology 31, 29-36. 
Dövényi, Z., 2010. Magyarország kistájainak katasztere.(Cadastre of hungarian geographical microregions). MTA Földrajztudományi Kutatóintézet, Budapest. (in Hungarian)

Floote, R.L., Grogan, P., 2010. Soil carbon accumulation during temperate forest succession on abandoned low productivity agricultural lands. Ecosystems 13, 795-812. https://doi.org/10.1007/s10021-010-9355-0

Füleky, G., Kertész, Á., Madarász, B., Fehér, O., 2004. Soils developed in volcanic material in Hungary, [In:] Óskarsson, H., Arnalds, Ó. (Eds.), Volcanic Soil Resources in Europe. Agricultural Research Institute, Reykjavík, 63-64.

Füleky, G., Jakab, S., Fehér, O., Madarász, B., Kertész, Á., 2007. Hungary and the Carpathian Basin. [In:] Arnalds, O., Bartoli, F., Buurman, P., Oskarsson, H., Stoops, G., García-Rodeja, E. (Eds.), Soils of Volcanic Regions in Europe. Springer Verlag, Berlin Heidelberg, 29-42.

Jastrow, J.D., 1996. Soil aggregate formation and the accrual of particulate and mineralassociated organic matter. Soil Biology and Biochemistry 28, 665-676. https://doi.org/10.1016/0038-0717(95)00159-X

John, B., Yamashita, T., Ludwig, B., Flessa, H., 2005. Storage of organic carbon in aggregate and density fractions of silty soils under different types of land use. Geoderma 128, 63-79. https://doi.org/10.1016/ j.geoderma.2004.12.013

Justyák, J., 1981. Characteristics of micro- and mezo climate of Tokaj-Hegyalja. [In:] Brezovcsik, L. 1981 (Ed.), Geoökológiai viszonyok néhány sajátossága Tokajhegyalján, Pusztai B. Tarcal, 13-42. (in Hungarian)

Kalinina, O., Goryachkin, S.V., Karavaeva, N.A., Lyuri, D.I., Najdenko, L., Giani, L., 2009. Self-restoration of post-agrogenic sandy soils in the southern taiga of Russia: Soil development, nutrient status, and carbon dynamics. Geoderma 152, 35-42. https://doi.org/10.1016/ j.geoderma.2009.05.014

Kalinina, O., Goryachkin S.V., Karavaeva N.A., Lyuri D.I., Giani L., 2010. Dynamics of carbon pools in post-agrogenic sandy soils of southern taiga of Russia. Carbon Balance and Management 5(1). https://doi. org/10.1186/1750-0680-5-1

Kalinina, O., Krause, S-E., Goryachkin, S.V., Karavaeva, N.A., Lyuri, D.I., Giani, L., 2011. Self-restoration of post-agrogenic chernozems of Russia: Soil development, carbon stocks, and dynamics of carbon pools. Geoderma 162, 196-206. https://doi.org/10.1016/j.geoderma.2011.02.005

Kalinina, O., Barmin, A.N., Chertov, O., Dolgikh, A.V., Goryachkin, S.V., Lyuri, D.I., Giani, L., 2014. Self-restoration of post-agrogenic soils of Calcisol - Solonetz complex: Soil development, carbon stocks and dynamics of carbon pools. Geoderma 237-238, 117-128. https://doi. org/10.1016/j.geoderma.2014.08.013

Kalinina,O., Goryachkin, S.V., Lyuri, D.I., Giani, L., 2015. Post-agrogenic development of vegetation, soils, and carbon stocks under self-restoration in different climatic zones of European Russia. Catena 129, 18-29. https://doi.org/10.1016/j.catena.2015.02.016

Kerényi, A., 1994. Loess erosion on the Tokaj Big-Hill. Quaternary International 24, 47-52. https://doi.org/10.1016/1040-6182(94)90038-8

Koulouri, M., Giourga, C., 2007. Land abandonment and slope gradient as key factors of soil erosion in Mediterranean terraced lands. Catena 69(3), 274-281. https://doi.org/10.1016/j.catena.2006.07.001

Leeschen, J.P., Cammeraat, L.H., Kooijman, A.M., van Wesemael, B., 2008. Development of spatial heterogeneity in vegetation and soil properties after land abandonment in a semi-arid ecosystem. Journal of Arid Environments 72(11), 2082-2092. https://doi.org/10.1016/ j.jaridenv.2008.06.006

Leifeld, J., Kögel-Knabner, I., 2005. Soil organic matter fractions as early indicators for carbon stock changes under different land-use? Geoderma 124, 143-155. https://doi.org/10.1016/j.geoderma.2004.04.009
Madarász, B., Németh, T., Jakab, G., Szalai, Z., 2013. The erubáz volcanic soil of Hungary: Mineralogy and classification. Catena 107, 46-56. https://doi.org/10.1016/j.catena.2013.02.004

McLauchlan, K., 2006. The nature and longevity of agricultural impacts on soil carbon and nutrients: a review. Ecosystems 9, 1364-1382. https://doi.org/10.1007/s10021-005-0135-1

Novák, T.J. , Incze, J., Spohn, M., Glina, B., Giani, L., 2014. Soil and vegetation transformation in abandoned vineyards of the Tokaj Nagy-Hill. Catena 123: 88-98. https://doi.org/10.1016/j.catena.2014.07.017

Nyizsalovszki, R., Fórián T., 2007. Human impact on the Landscape in the Tokaj Foothill Region, Hungary. Geografia Fisica e Dinamica Quaternaria 30, 219-224.

Pansu, M.,Gatheyrou, J. 2006. Handbook of soil analysis, Springer Verlag, Berlin-Heidelberg, 35-42.

Pécskay, Z., Lexa, J., Szakács, A., Balogh, K., Seghedi, I., Konečny, V., Kovács, M., Márton, E., Kaličak, M., Széky-Fux, V., Póka, T., Gyarmati,P., Edelstein, O., Rosu, E., Žec, B., 1995. Space and time distribution of Neogene-Quaternary volcanism in the Carpatho-Pannonian region. Acta Vulcanologica 7(2), 15-28.

Poeplau, C., Don, A., 2013. Sensitivity of soil organic carbon stocks and fractions to different land-use changes across Europe. Geoderma 192, 189-201. https://doi.org/10.1016/j.geoderma.2012.08.003

Ponomareva, V.V., Plotnikova, T.A., 1980. Gumus i Pochvoobrazovanie (Humus and Pedogenesis), Nauka, Leningrad. 65-74.

Rózsa, P., Szöőr, G., Elekes, Z., Gratuze, B., Uzonyi, I, Kiss, Á.Z., 2006. Comparative geochemical studies of obsidian samples from various localities. Acta geologica Hungarica 49(1), 73-87.

Rózsa, P., 2007. Attempts at qualitative and quantitative assessment of human impact on the landscape. Geografia Fisica e Dinamica Quaternaria 30(2), 233-238.

Schmidt, M.W.I., Rumpel, C., Kögel-Knabner, I., 1999. Evaluation of an ultrasonic dispersion procedure to isolate primary organomineral complexes from soils. European Journal of Soil Science 50, 87-94. https://doi.org/10.1046/j.1365-2389.1999.00211.x

Sendtko, A., 1999. Succession of xerothermic vegetation in abandoned vineyards of the Tokaj region (northeastern Hungary): Studies in phytosociology and population biology. Phytocoenologia 29, 345-448. https://doi.org/10.1127/phyto/29/1999/345

Six, J., Elliott, E.T., Paustian, K., Doran, J.W., 1998. Aggregation and soil organic matter accumulation in cultivated and native grassland soils. Soil ScienceSociety ofAmerica Journal 65, 1367-1377. https://doi. org/10.2136/sssaj1998.03615995006200050032x

Spohn, M., Novák, T.J., Incze, J., Giani, L., 2015. Dynamics of soil carbon, nitrogen, and phosphorus in calcareous soils after land-use abandonment - A chronosequence study. Plant and Soil 401(1),185-196. https://doi.org/10.1007/s11104-015-2513-6

Stefanovits, P., Filep, G., Füleky, G., 1999. Talajtan (Pedology). Mezőgazda Kiadó, Budapest. (in Hungarian)

Steffens, M., Kölbl, A., Kögel-Knabner, I., 2009. Alteration of soil organic matter pools and aggregations in semiarid steppe topsoils as driven by OM input. European Journal of Soil Science 60(2), 198-212. https:// doi.org/10.1111/j.1365-2389.2008.01104.x

Vance, E.D., Brookes P.C., Jenkinson, D.S., 1987. An extraction method for measuring soils microbial biomass-C. Soil Biology and Biochemistry 19, 703-707. https://doi.org/10.1016/0038-0717(87)90052-6

VDLUFA - (Verband Deutscher Landwirtschaftlicher Untersuchungsund Forschungsanstalten e.V.) Methodenbuch 2004. A.4.3.2. Heisswasserextrahierbarer Kohlenstoff und Stickstoff. $4^{\text {th }}$ edition, Darmstadt. ISBN 978-3-941273-30-5. 